\title{
Optical Properties of Chromophoric Dissolved Organic Matter in the Yinma River Watershed and Drinking Water Resource of Northeast China
}

\author{
Sijia Li ${ }^{1}$, Jiquan Zhang ${ }^{1 *}$, Guangyi $\mathrm{Mu}^{2}, \mathrm{Si} \mathrm{Ha}^{1}$, Caiyun Sun${ }^{1}$, \\ Hanyu Ju' ${ }^{1}$, Feng Zhang, Yanan Chen ${ }^{1}$, Qiyun $\mathrm{Ma}^{1}$ \\ ${ }^{1}$ Nature Disaster Research Institute, Environment College, Northeast Normal University, \\ Chang Chun 130024, People's Republic of China \\ ${ }^{2}$ Grassland Science Institute, Life Science College, Northeast Normal University, \\ Chang Chun 130000, People's Republic of China
}

Received: 22 November 2015

Accepted: 1 February 2016

\begin{abstract}
Spectral characteristics of optically active constituents (OACs) in waters are key parameters of biooptical modeling. Comparative analyses about the differences of optical characteristics and composition between riverine and reservoir waters in the second Songhuajiang River tributaries were conducted, and the influencing factors impacting on chromophoric dissolved organic matter (CDOM) and organic carbon (DOC) were examined based on the absorption properties. Dissolved organic carbon (DOC) and total suspended matter (TSM) were significantly higher in the riverine waters, and chlorophyll-a (Chl-a) was opposite. The relationship between the CDOM absorption coefficient at specific wavelength and DOC concentration both in the riverine and reservoir waters exhibited a positive correlation $(\mathrm{r}=0.90, p<0.01)$. The close relationship between Chl-a concentration and CDOM absorption confirmed a small amount of phytoplankton absorption to total absorption in the individual samplings. Analysis of absorption ratio $\left(E_{250: 365}\right)$, specific UV absorbance $\left(\mathrm{SUVA}_{254}\right)$, and spectral slope ratio $\left(S_{\mathrm{r}}\right)$ indicated that CDOM in riverine waters had lower aromaricity, molecular weight, and vascular plant contributions than in reservoir waters. Furthermore, non-algal particles played an important role in the total non-water absorption for riverine waters, and CDOM was dominant in the reservoir waters. This indicated that the Yinma River watershed was strongly influenced by the artificial discharge. As a parameter of the bio-optical model, the spectral characteristics of CDOM could help to adjust derived algorithms based on remote sensing and to estimate the dissolved organic carbon flux.
\end{abstract}

Keywords: chromophoric dissolved organic matter, optical properties, Yinma River, Shitoukoumen Reservoir

*e-mail: zhangjq022@nenu.edu.cn 


\section{Introduction}

Dissolved organic matter (DOM), the largest reservoir of organic carbon on earth [1], is an important substrate for microorganisms fueling microbial metabolism, including bacteria and algae in aquatic ecosystems [2-3]. With respect to human health, DOM provides us with stro ng absorption of toxic substances (e.g., mercury) in rivers, streams, and drinking waters [4-5]. DOM is introduced into the aquatic systems through autochthonous production, e.g., phytoplankton excretion, zooplankton, and bacterial metabolism [6], and allochthonous, e.g., terrestrial inputs and human-related contamination [7].

The research focus on the flux of DOM derived from terrestrial net ecosystem production on entering aquatic environments represents an essential link between terrestrial and aquatic ecosystems [8]. Chromophoric dissolved organic matter (CDOM) represents the optically active fraction of DOM in natural waters and is often viewed as a reliable tracer of dissolved organic carbon (DOC) [9-12]. CDOM provides us with unique chemical properties, absorption characteristic in the ultraviolet (UV), and visible ranges of the light spectrum [13]. Hence, it shows many aspects of biochemistry and optical-physics transformations and significance [14], e.g., it influences light attenuation of ultraviolet radiation penetration through the waters and protects aquatic organisms [1416]; affects material transport, biological effect (trace metal and organic pollutant), and ecosystem productivity [17-18]; and increases the complexity about the inversion accuracy of remote sensing of chlorophyll-a and other suspended solids [11, 19-21].

Despite comprising a relatively small fraction of DOM, the strong relationships between CDOM absorption and DOM in coastal waters provide a means to quantify DOC (i.e., export of DOC flux) as well as sources and sinks of DOM from satellite retrievals of CDOM absorption [22].

Notwithstanding the importance of DOC, other research has shown that riverine export of DOC provides the largest flux of reduced carbon from land to ocean (0.25 $\left.\mathrm{Pg} \mathrm{C} \mathrm{yr}^{-1}\right)$, as current DOC flux estimates are lower $\left(0.18 \mathrm{Pg} \mathrm{C} \mathrm{yr}^{-1}\right)[2,5,23]$. Compared to the oceanic or coastal waters, the allochthonous source is proposed as a critical factor to determine the temporal and spatial variations of DOM in inland waters [24]. Especially for river ecosystems, they face a range of stressors from landuse changes (e.g., deforestation, conversion to agriculture, urbanization) and engineering (e.g., channelization, impoundment). Furthermore, terrestrial DOC export is often associated with riverine transport of trace metals, pollutants, and pathogens. Hence, understanding the production, transport and fate of DOC in rivers and streams is not only the direct relevance to studies addressing issues from water quality to the bacterioplankton community structure and function, but also close links to safety, agriculture, and residential environment.
However, CDOM and DOC relationships are complicated and are affected by environmental, and anthropogenic factors, and other ecological effects such as defoliation and algal bloom [10]. Much research has shown that CDOM from relatively CDOM-rich inland freshwaters is greatly influenced by allochthonous sources from land surface processes [25]. Particularly in highly dynamic periods (e.g., storms and spring freshets), both DOC concentration and DOM composition change rapidly with concurrent shifts in biolability [22]. Recently the development of in-situ technologies will allow for strengthening the understanding of DOC's biogeochemical role within aquatic environments.

Biogeochemical processing of DOM quality (e.g., photochemical or microbial degradation) has been related to CDOM parameters $[6,22]$. In order to characterize the spatial and temporal CDOM variations in aquatic environments, spectral analysis of CDOM (absorption and fluorescence) can trace its origin and chemical composition [26-27]. Based on the characteristics of the absorption spectrum, spectral indices (e.g., absorption coefficient at specific wavelength), absorption ratio $\left(E_{250: 365}\right)$, spectral slopes $\left(S, S_{275-295}\right.$ and $\left.S_{350-400}\right)$, the ratio of $S_{275-295}$ and $S_{350-400}$, and $\mathrm{SUVA}_{254}$ values have been developed to trace DOM source, molecular size, and aromatic hydrocarbon content, etc. [28]. Research has shown that dissolved lignin and phenolic substances (vacular plant) have a significantly positive correlation with $a_{\mathrm{CDOM}}(350)$ in various waters, e.g., waters in Hulun plateau [12] and the Congo [9], Liaohe [29], and Elizabeth [30] rivers. Nelson et al. (2010) [31] found that CDOM is strongly correlated to apparent oxygen utilization, and it could potentially be used as a tracer of biogeochemical processes in global oceans. Meanwhile, fluorescence spectroscopy as an effective method could differentiate fluorophores and characterize CDOM in various water masses [32-33].

As an important tributary of the Songhua fluvial system, water quality in the Yinma River watershed has been highly polluted in the past three decades due to the fast economic development of agriculture and industry [34]. The accumulation of heavy metals in sediments and bioaccumulation of benthic organisms were highlighted for the Songhua fluvial system [35]. The modification in carbon cycle processes should be better understood through quantitative estimation and monitoring of CDOM in riverine environments, and highlight the potential utility of the algorithms for deriving DOC concentrations in the surface layer - especially examining the timing of DOC flux in highly dynamic periods (e.g., storms, snowmelt) [36-37]. Not just estimating DOC concentration but also DOM composition via CDOM holds great potential. This paper uses the CDOM absorption spectrum, relative contribution of CDOM, absorption coefficients, and spectral slope to examine compositional distribution and CDOM variation in the Yinma River watershed. It is useful for the development of a bio-optical model and remote sensing algorithm investigations for inland waters. 


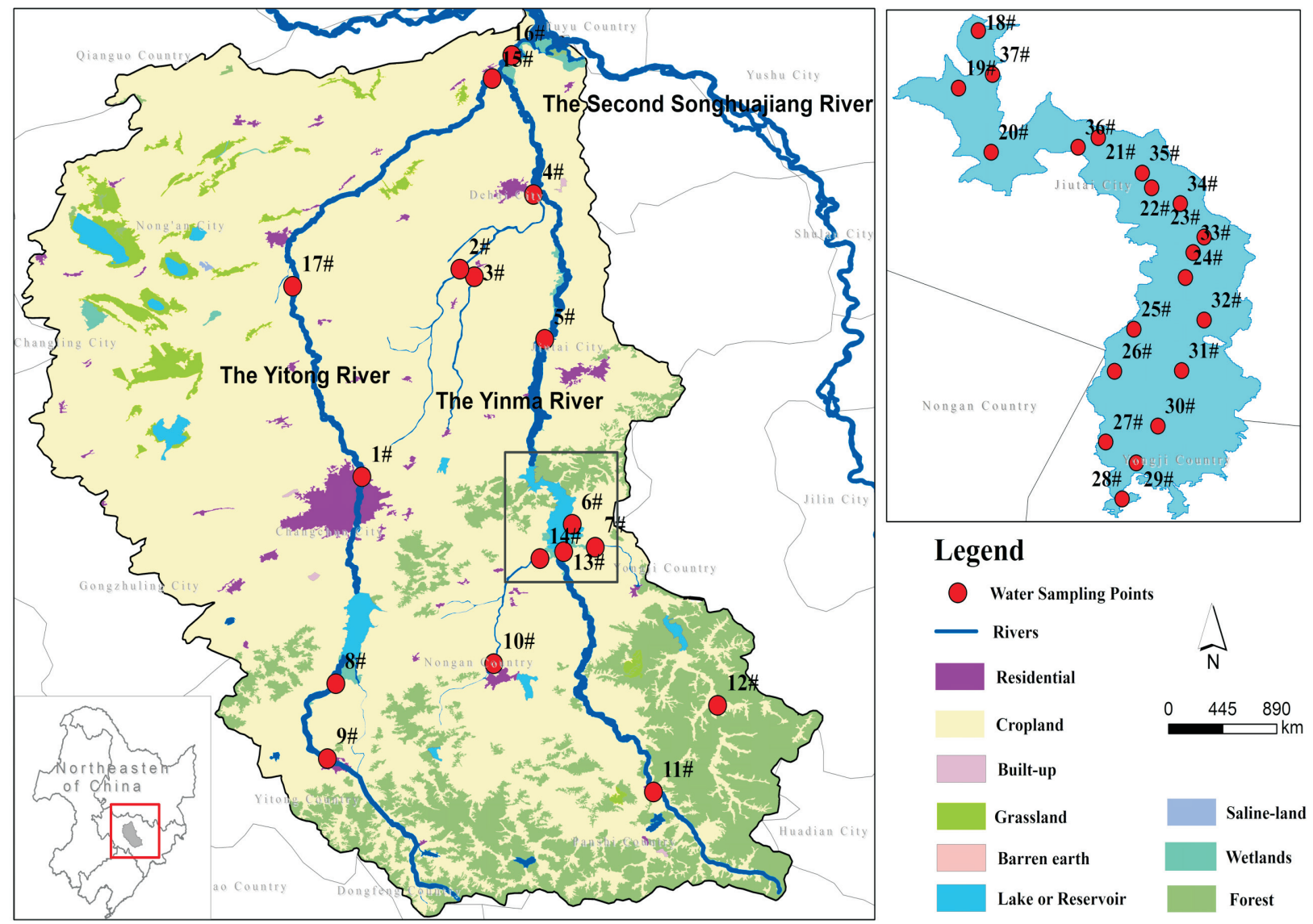

Fig. 1. Location and sampling points of study area, including Shitoukoumen Reservoir (STKM, 20 sampling points from Nos. 18 to 37), Yitong River (YT, 11 sampling points, including Nos. 1-3, 15, 17), Yinma River (YM, 11 sampling points, including Nos. 4-14) and No. 16 at the confluence of the Yinma and Yitong rivers.

\section{Material and Methods}

\section{Study Area}

The Yinma River watershed $\left(124^{\circ} 58^{\prime} \sim 126^{\circ} 24^{\prime} \mathrm{E}\right.$, $43^{\circ} 02^{\prime} \sim 44^{\circ} 53^{\prime} \mathrm{N}$ ), an important tributary of the Songhua fluvial system, is located in central Jilin Province, China (Fig. 1). The area of watershed is about $1.74 \times 10^{4} \mathrm{~km}^{2}$, including two main rivers: the Yinma and Yitong. The region is typical of the northern temperate zone continental monsoon climate, with a frozen period of about 150 days [34]. It has distinct seasons with a windy spring, a hot and rainy summer, a large temperature difference in autumn, and a cold dry winter. The mean annual temperature is $273.45 \mathrm{~K}$, yearly average precipitation ranges from 370 to $668 \mathrm{~mm}$, and evaporation is $1,438.4 \mathrm{~mm}$. Ultimately the Yinma merges with the Yitong and flows to the second Songhua fluvial system. Shitoukoumen Reservoir $\left(125^{\circ} 43^{\prime} \sim 125^{\circ} 51^{\prime} \mathrm{E}, 43^{\circ} 47^{\prime} \sim 43^{\circ} 57^{\prime} \mathrm{N}\right)$ is a major potable water source for Changchun, the capital of Jilin Province. The reservoir is $35 \mathrm{~km}$ from Changchun and provides more than $80 \%$ of the drinking water for the metropolitan area, which has 3.5 million residents. The average water surface area is $94.2 \mathrm{~km}^{2}$ with a capacity of 702 million $\mathrm{m}^{3}$ and average depth of $3.3 \mathrm{~m}$.

\section{In-situ Data Collection and Processing}

Water samples at 17 sites in the watershed were taken from the surface layer (0-0.5 m) during 19t-22 August 2015 (Fig. 1). Coordinates for water sample sites were recorded by GPS (G350, UniSreong, China), water clarity was measured with a Secchi disk (SDD), and conductivity, $\mathrm{pH}$, and temperature were determined by YSI multi-parameter probes (YSI6600,US). It's notable that the Perspex water sampler and Niskin bottles were rinsed before collecting. The sample was collected approximately $2.5 \mathrm{~L}$ at each site and immediately kept on ice for transport or in a refrigerator for longer-term storage (which belongs to the Environment Institute, Northeast Normal University). Physical and chemical parameters, e.g., Chlorophyll-a (Chl-a), DOC concentration, and particulate and CDOM absorption were determined within six hours from water samplings.

\section{Measurement of Absorbance and Processing}

According to the quantitative filter technique (QFT, quantitative membrane filter technique), the particulates were filtered under low vacuum through a $0.45-\mu \mathrm{m}$ grass fiber membrane (Whatman, GF/F 1825-047). Absorbance 
of the filtrate was measured between $400 \mathrm{~nm}$ and $700 \mathrm{~nm}$ at $1 \mathrm{~nm}$ interval using a Shimadzu UV-2600 spectrophotometer with Milli-Q water as a reference. Scan settings for the spectrophotometer are as follows: $4 \mathrm{~nm}$ slit width, 250-800 nm wavelength range, $1 \mathrm{~nm}$ data interval, and $100 \mathrm{~nm}^{-1}$ scan rate. The absorbance of nonalgal particles were bleached by $0.1 \%$ sodium hypochlorite. The absorbance of phytoplankton was calculated by total particulate subtracted from nonalgal particles.

Likewise, the CDOM was extracted from the water samples by filtering through $0.45-\mu \mathrm{m}$ grass fiber membrane and then through a $0.22-\mu \mathrm{m}$ polycarbonate membrane (Whatman, 110606). The absorbance of the filtered water was then measured in a 1-cm quartz cuvette between 200 and $800 \mathrm{~nm}$ with $1-\mathrm{nm}$ increments using a Shimadzu UV-2006. More detailed description of measuring absorption coefficients could be found in Song et al. (2012) [38]. In order to eliminate the backscattering, the absorbance at $700 \mathrm{~nm}$ was used to correct absorption coefficients [39]. The absorption coefficient $\left(a_{\mathrm{CDOM}}\right)$ was calculated by the measured water optical density (OD) following the Eq. (1):

$$
a_{C D O M}\left(\lambda^{\prime}\right)=2.303 \cdot O D_{\lambda} / L
$$

...where $a_{\mathrm{CDOM}}\left(\lambda^{\prime}\right)$ is the uncorrected CDOM absorption coefficient at given $\lambda, O D(\lambda)$ is the optical density at the same wavelength, and $L$ is the cuvette path length in meters. Absorbance was then converted to the absorption coefficient for total particulate, $a(\lambda)$; nonalgal particles, $a_{\mathrm{d}}(\lambda)$; phytoplankton, $a_{\mathrm{ph}}(\lambda)$, and CDOM, $a_{\mathrm{CDOM}}(\lambda)$. The total absorption coefficient is the sum of $a_{\mathrm{d}}(\lambda), a_{\mathrm{ph}}(\lambda)$, $a_{\mathrm{CDOM}}(\lambda)$, and $a_{\mathrm{w}}(\lambda)$, where $a_{\mathrm{w}}(\lambda)$ represents pure water absorption derived from Pope et al. (1997) [40].

\section{Water Quality Measurement}

In order to prevent pigment denaturalization, water samples were immediately filtered under low vacuum. Water samples for chlorophyll-a extraction were passed through a $0.45 \mu \mathrm{m}$ fiber membrane, after which chlorophyll-a was extracted with $90 \%$ acetone for 48 hours under subdued light conditions. The concentrations were determined with a UV spectrophotometer (Shimadzu, UV-2006PC); the detailed process can be found in Song et al. (2012) [38]. Total suspended matter (TSM) was determined by gravimetrical analysis, and a more detailed description of measuring absorption coefficients could be found in Song et al. (2012) [38]. Dissolved organic carbon (DOC) was calculated by subtracting dissolved inorganic carbon (DIC) from total dissolved carbon (TDC) by hightemperature catalytic oxidation $(953.15 \mathrm{~K})$ using a total organic carbon analyzer (Shimadzu, TOC-VCPN).

\section{Parameterization and Statistical Analysis}

The absorption coefficients at wavelengths 335 $\mathrm{nm}\left[a_{\mathrm{CDOM}}(335)\right], 375 \mathrm{~nm}\left[a_{\mathrm{CDOM}}(375)\right]$, and $440 \mathrm{~nm}$
$\left[a_{\mathrm{CDOM}}(440)\right]$ were widely accepted as the proxy of CDOM concentration [41]. Specific UV absorbance (SUVA) values of the samplings were calculated by multiplying DOC concentration-normalized UV absorbance at $254 \mathrm{~nm}$ by a factor of 100 (i.e., $100 \times \mathrm{UV}_{254} / \mathrm{DOC}$ ) [28]. $\mathrm{SUVA}_{254}$ was determined using absorbance at $254 \mathrm{~nm}$ by the DOC concentration $\left(\mathrm{mg} \cdot \mathrm{L}^{-1}\right)$, which has a bearing on the content of aromatic hydrocarbon in DOM [28]. According to previous studies $[5,28,17]$, low $\mathrm{SUVA}_{254}$ indicates that the autochthonous sources dominated the organic matter content, conversely high $\mathrm{SUVA}_{254}$ represents the allohthonous sources with more vascular plant inputs. $E_{250: 365}$, also related to the content of aromatic hydrocarbon, can trace the molecular size of DOM [42-43]. Humic acid (HA) makes up a high proportion of CDOM from terrestrial inputs, as well as fulvic acid (FA) of CDOM from phytoplankton degradation. CDOM spectral slope coefficient $S$ provides further information on the type and source of CDOM. $S_{275-295}$ and $S_{350-400}$ between wavelengths 275-295 $\mathrm{nm}$ and 350-400 $\mathrm{nm}$ were both calculated using a nonlinear fit of an exponential function to absorption spectrum according to Eq. (2) [39]:

$$
a_{C D O M}(\lambda)=a_{C D O M}\left(\lambda_{0}\right) \cdot \mathrm{e}^{S\left(\lambda_{0}-\lambda\right)}
$$

...where $a_{\mathrm{CDOM}}(\lambda)$ is the CDOM absorption at a given wavelength and $a_{\mathrm{CDOM}}\left(\lambda_{0}\right)$ is the reference wavelength $(440 \mathrm{~nm}) . S_{\mathrm{r}}$ was represented by the ratio of $S_{275-295}$ and $S_{350-400}$ to avoid the limitations of spectral wavelength measurements [5]. Lower $S_{\mathrm{r}}$ values contained greater allochthonous and higher molecular weight DOM. The effectiveness of $S_{\mathrm{r}}$ has been demonstrated with CDOM samples from various waters, ranging from DOC-rich wetlands to photobleached coastal waters and lakes over high-altitude plateaus $[29,44]$. The coefficient of variation $(\mathrm{CV})$ is computed from the filtered mean and standard deviation of values.

\section{Results and Discussion}

\section{Water Quality}

The samples collected in riverine and reservoir waters exhibited large variations in water quality (Fig. 3 ), indicating the presence of complex optical active constituents. A significant difference of TSM was also observed (the same as Chl-a concentration). The DOC concentration ranged from 2.43 to $14.44 \mathrm{mg} \mathrm{L}^{-1}$ in riverine waters, and exhibited lower values in Shitoukoumen Reservoir (STKM) (3.64-6.27 $\mathrm{mg} \mathrm{L}^{-1}$ ). Furthermore, the average DOC concentration in rivers $\left(5.62 \pm 2.9 \mathrm{mg} \mathrm{L}^{-1}\right)$ was obviously lower than in lakes (e.g., terminal waters with high electrical conductivity) reported in other studies [12, 45]. Jiang et al. (2014) [25] found that DOC levels in rivers are linked to climate and watershed landscape characteristics. The difference of DOC between the Yitong and Yinma rivers may explain the pattern (Fig. 2). No. 1 


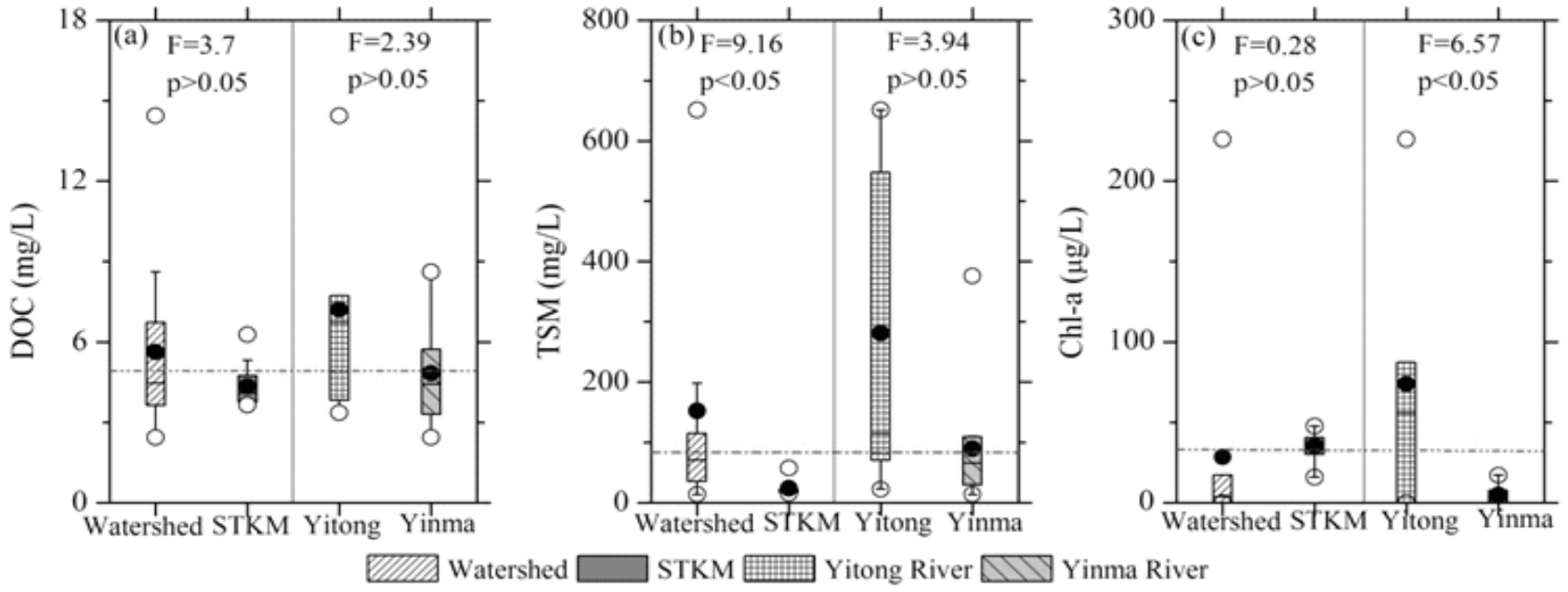

Fig. 2. Box plots of dissolved carbon, total suspended matter, and chlorophyll-a in the watershed, Yitong River, Yinma River, and STKM Reservoir: a) DOC concentration $(\mathrm{mg} / \mathrm{L})$, b) Total suspended matter $(\mathrm{mg} / \mathrm{L})$, and c) Chlorophyll-a concentration $(\mu \mathrm{g} / \mathrm{L})$. The black line and the filled circles represent the median and mean, respectively. The horizontal edges of the boxes denote the $25^{\text {th }}$ and $75^{\text {th }}$ percentiles; the whiskers denote the $10^{\text {th }}$ and $90^{\text {th }}$ percentiles, and the circles represent outliers. The dash dot lines represent the average values in all the samplings.

in the Yitong presented the highest DOC concentration (14.44 $\left.\mathrm{mg} \mathrm{L}^{-1}\right)$. The possible cause for this was DOM along with other nutrients coming from urban sewage. Consecutive DOM accumulated in No. 1 due to the lower microbial activity.

The average TSM concentration in rivers $\left(152.24 \pm 189.9 \mathrm{mg} \mathrm{L}^{-1}\right)$ was higher than in the reservoir $\left(23.79 \pm 11.23 \mathrm{mg} \mathrm{L}^{-1}\right)$ due to the riverine drain and shallow waters in the STKM reservoir causing sediment re-suspension from the bottom. TSM concentration in the Yitong $\left(281.13 \pm 294.6 \mathrm{mg} \mathrm{L}^{-1}\right)$ was higher than in the Yinma $\left(89.49 \pm 100.7 \mathrm{mg} \mathrm{L}^{-1}\right)$. No. 1 in the Yitong especially showed the opposite result with DOC and Chl-a. High loads of suspended matter prevented phytoplankton from growing due to light limitations. Totally, average Chl-a concentration in the riverine waters $(28.34 \pm 57.25$ $\left.\mu \mathrm{g} \mathrm{L}^{-1}\right)$ was lower than the reservoir waters $(35.32 \pm 8.16$ $\left.\mu \mathrm{g} \mathrm{L}^{-1}\right)$, and Chl-a was higher in the Yitong than in the Yinma (Fig. 2). No. 1 in Changchun possessed the highest Chl-a concentration $\left(225.98 \mu \mathrm{g} \mathrm{L}^{-1}\right)$, and there appeared many algae floating like green ribbons on the surface of the river. Continuous sewage from nearby chemical factories was discharged into the river, which may have caused the eutrophication. The input of fertilizer in the cropland resulted in the high Chl-a concentration (e.g., Nos. 15 and 17 in the Yitong). Compared to the water quality concentration, rivers were greatly influenced by the surrounding landscape and showed more prominent spatial heterogeneity than in the reservoir.

\section{Spectral Characteristics of CDOM Absorption}

CDOM absorption spectra typically decreases in an approximately exponential fashion, increasing from ultraviolet (UV) to visible wavelengths, and the accuracy of CDOM measurements decreases at longer wavelengths
[46]. Noting the high standard deviations for these values reaching $\sim 50 \%$ indicating high spatial and temporal variability in $a_{\mathrm{CDOM}} \mathrm{CDOM}$ absorption coefficients at specific wavelength has often been used as a surrogate for colored DOM [47-48]. Much research has confirmed that there is a significant correlation between DOC and CDOM [49-50], and occasionally there is no covariant [7]. The average values of $a_{\mathrm{CDOM}(335)}, a_{\mathrm{CDOM}(375)}$, and $a_{\mathrm{CDOM}(440)}$ in reservoir waters both exhibited significantly higher CDOM light absorption than in riverine waters (Table 1). The comparative analysis in the two rivers showed that the Yitong showed higher average values. This suggested that CDOM concentration for reservoir waters was higher than riverine waters.

Influenced by the watershed landscape, $a_{\mathrm{CDOM}}$ in riverine waters compared with the reservoir exhibited high temporal variability (Fig. 4). This indicated that the allochthonous DOM sources may contain a larger fraction of CDOM within the total pool of DOM compared to the lake DOM. For this, using a similar geographical aquatic environment such as riverine waters, we could randomly select CDOM absorption coefficient and spectral slope to estimate the light absorption spectrum or the contributions of optical active substances.

In order to confirm the sources and composition of CDOM from different regions, the spectral slopes $S_{275-295}$, $S_{\mathrm{r} \text {, }}$ and absorption ratio $E_{250: 365}$ were calculated as indicators. As shown in Table 1, the average $E_{250: 365}$ values were $11.66 \pm 11.50$ and $5.50 \pm 1.02$ in the riverine and reservoir waters, respectively. The Yinma River $(19.89 \pm 17.20)$ showed higher average $E_{250: 365}$ value than the Yitong $(8.31 \pm 6.69)$. The high values of $E_{250: 365}$ observed in reservoir waters may be regulated by DOC flux for inland waters in time and space [44-45]. Increasing $E_{250: 365}$ values indicates a decrease in aromaticity and molecular weight of CDOM, but reservoir waters had higher aromaticity and 

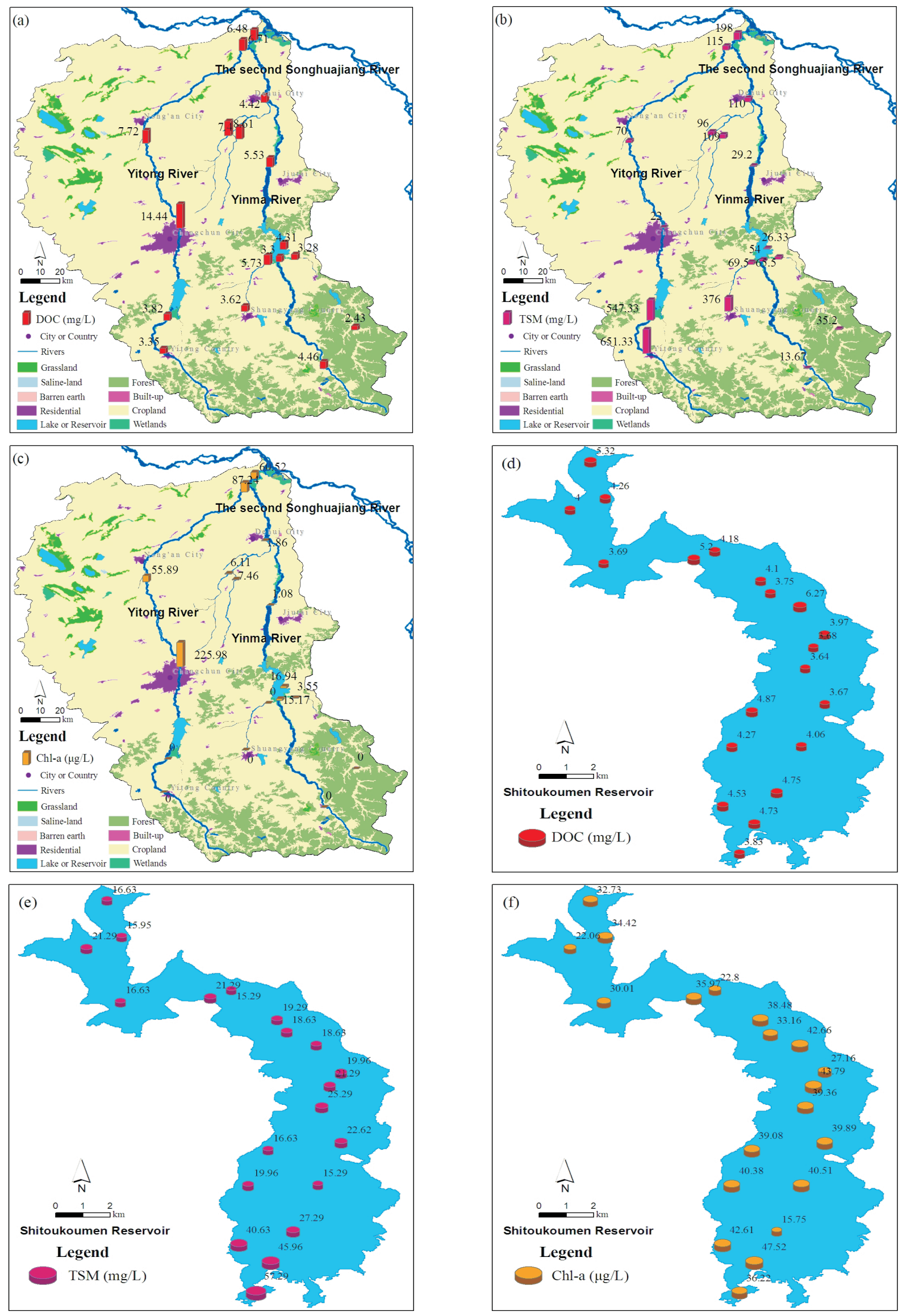

Fig. 3. The spatial distribution of water quality: a) the DOC concentration of riverine waters, b) the TSM concentration of riverine waters, c) the Chl-a concentration of riverine waters, d) the DOC concentration of reservoir waters, e) the TSM concentration of reservoir waters, and f) the Chl-a concentration of reservoir waters. 
molecularity than riverine waters. Likewise, the average $S$ exhibited higher values in reservoir $(1.34 \pm 0.19)$ than in riverine waters $(0.63 \pm 0.43)$, and the $S_{\mathrm{r}}$ in two rivers ranged from $0.58 \pm 0.53$ to $0.62 \pm 0.42$. Lower $S_{\mathrm{r}}$ values indicated that the allochthonous source dominates, showing an identical trend with $E_{250: 365}$. The riverine waters showed higher $S_{275-295}$ than in the reservoir, consistent with other studies [12, 38]. Previous studies have proven that $S$ values were inversely proportional to $\mathrm{CDOM}$ molecular weight [1]. Higher $S$ values indicated the percentage of low molecular weight fulvic acid in CDOM in riverine waters, signifying a decrease in aromaticity content.

As an effective index to characterize the DOC concentrations, the average $\mathrm{SUVA}_{254}$ ranged from $3.97 \pm 1.35 \mathrm{~L} \mathrm{mg} \mathrm{C}^{-1} \mathrm{~m}^{-1}$ in the riverine waters to $6.54 \pm 0.74 \mathrm{mg} \mathrm{C}^{-1} \mathrm{~m}^{-1}$ in reservoir waters (Table 1). SUVA $_{254}$ ranged from $2.30 \pm 0.14 \mathrm{~L} \mathrm{mg} \mathrm{C}^{-1} \mathrm{~m}^{-1}$ to $8.70 \pm 2.80 \mathrm{~L} \mathrm{mg} \mathrm{C}^{-1} \mathrm{~m}^{-1}$ in Songnen Plain [45], and 3.08 to $3.57 \mathrm{~L} \mathrm{mg} \mathrm{C}^{-1} \mathrm{~m}^{-1}$ in the Epula River from the tropical zone due to photosynthetic degradation and bleaching. SUVA 254 revealed that the contribution of vascular plant matter to DOM in rivers might be greater than the reservoir waters, and low molecular weight DOM was more abundant. According to the spatial distribution of water quality, parameters (Fig. 5), parts of samplings showed zero-concentration of Chl-a. Meanwhile, large average value was observed in the Yinma River, ranged from $4.21 \pm 1.37 \mathrm{mg} \mathrm{C}^{-1} \mathrm{~m}^{-1}$ to $3.29 \pm 1.29 \mathrm{mg} \mathrm{C}^{-1} \mathrm{~m}^{-1}$ in Yitong River. In comparison to Yitong River, terrigenous inputs in Yima River increase the SUVA $_{254}$ values. Our study results close to the SUVA $_{254}$ in the Songnen Plain waters ranged from (2.3 8.7) [45], and were significantly higher than other reported rivers [5]. It indicated that the aromatic moieties of CDOM in this environment were lower compared with reservoir waters, consistent with the trend of $E_{250: 365}, S_{\mathrm{r}}$ and $S_{275-295^{\circ}}$. Previous studies [12, 45] showed riverine waters have less residence times due to the high lowability and quick exchange rates of flow water enhanced terrestrial DOC input, and more high molecular weight humic acid were examined. However, this opposite phenomenon was exhibited in terminal waters (e.g., reservoirs or lakes) due to the effect of photodegradation and microbial degradation with prolonged water residence times. High molecular weight of CDOM is destroyed by photolysis and irradiation due to the bond cleavage, resulting in its transformation to a low molecular weight pool [9]. Compared with the reported riverine waters $[5,12,17,29,45]$, our studies presented significantly opposite results. However, the steep $S_{250-275}(0.0194)$ of CDOM and CDOM portion to fulvic acid were found in the Mississippi River [51]. Due to the high spectral scopes in shorter wavelength, near-zero absorption coefficient in longer wavelength (350-400 nm) and low concentration of CDOM were found. Meanwhile, $S_{\mathrm{r}}$ in the $17 \#, 1 \#, 13 \#, 10 \#$ and 11\# showed zero values, especially the $E_{250: 365}$ in 17\#, 1\# (Yitong River) and 10\#, 11\# (Yinma river). As observed for slope ratio $S_{\mathrm{r}}$ of $S_{250-275}: S_{350-400}$ and $S_{250-275}$ in Fig. 5, the shallowest average $S_{350-400}$ values were analogous to data sets reported from aquatic ecosystems with high allochthonous inputs such as Congo River [9]. The landuse types (Fig. 1) and CDOM absorption parameters in different samplings (Fig. 5 and Table 1) showed the lower aromaticity and molecular weight of CDOM in Nos. 17 and 1, and the opposite in Nos. 10 and 11. In comparison to Nos. 17 (cropland) and 11 (cropland and forest), Nos. 1 and 10 were mainly influenced by sewage water with different composition of DOM from city or country.

Along with the longer residence time, DOC concentration decreases for inland waters in the damp area. In semi-arid or arid areas, the changes of DOC generally showed the opposite results with high alkalinity and conductivity in the terminal water [45].On the whole, soil brings more humic acid into the river, and humic acid
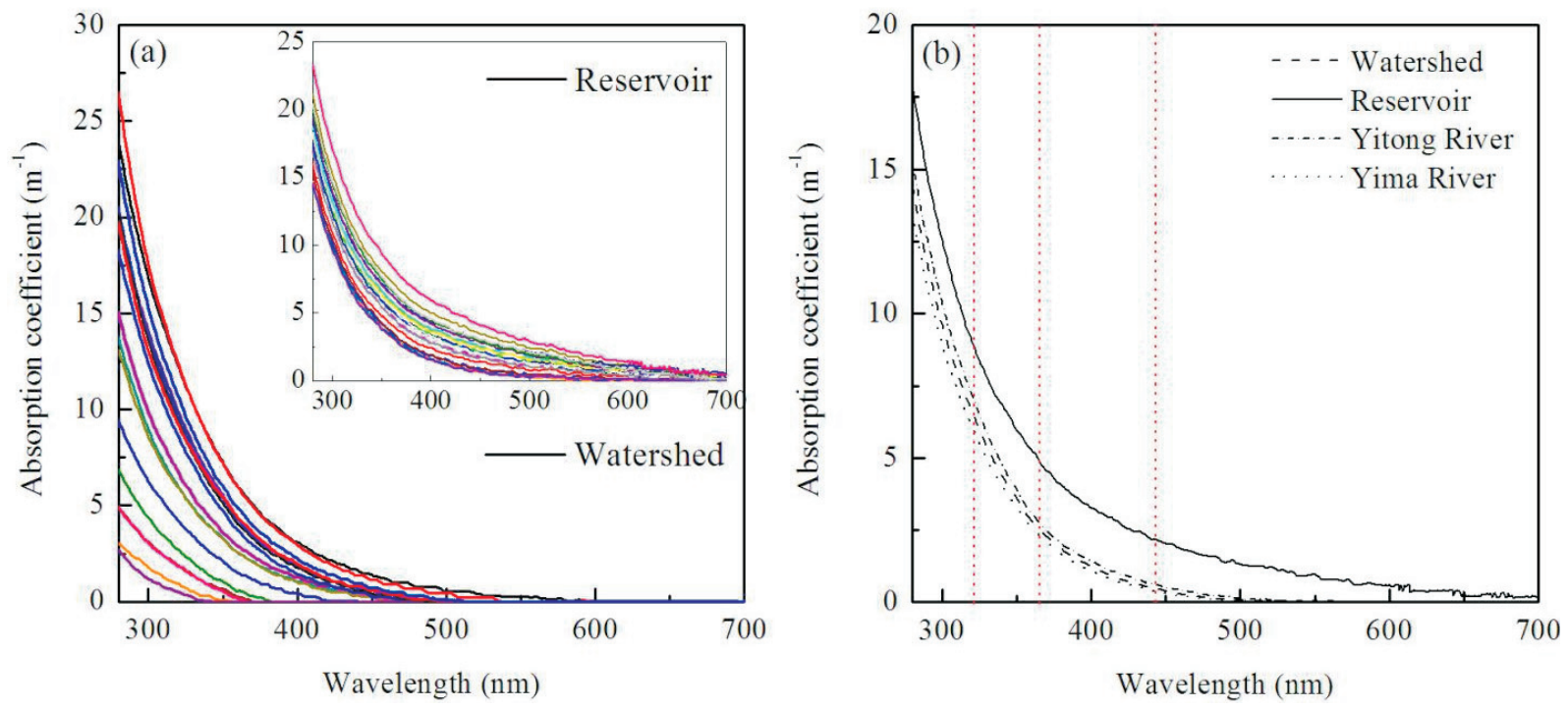

Fig. 4. Absorption characteristics of the riverine and reservoir water samples: a) absorption spectra of CDOM $\left(a_{\mathrm{CDOM}}\right)$ and b) average absorption spectra of CDOM $\left(a_{\mathrm{CDOM}}\right)$. The red line marks 335,375 , and $440 \mathrm{~nm}$. 


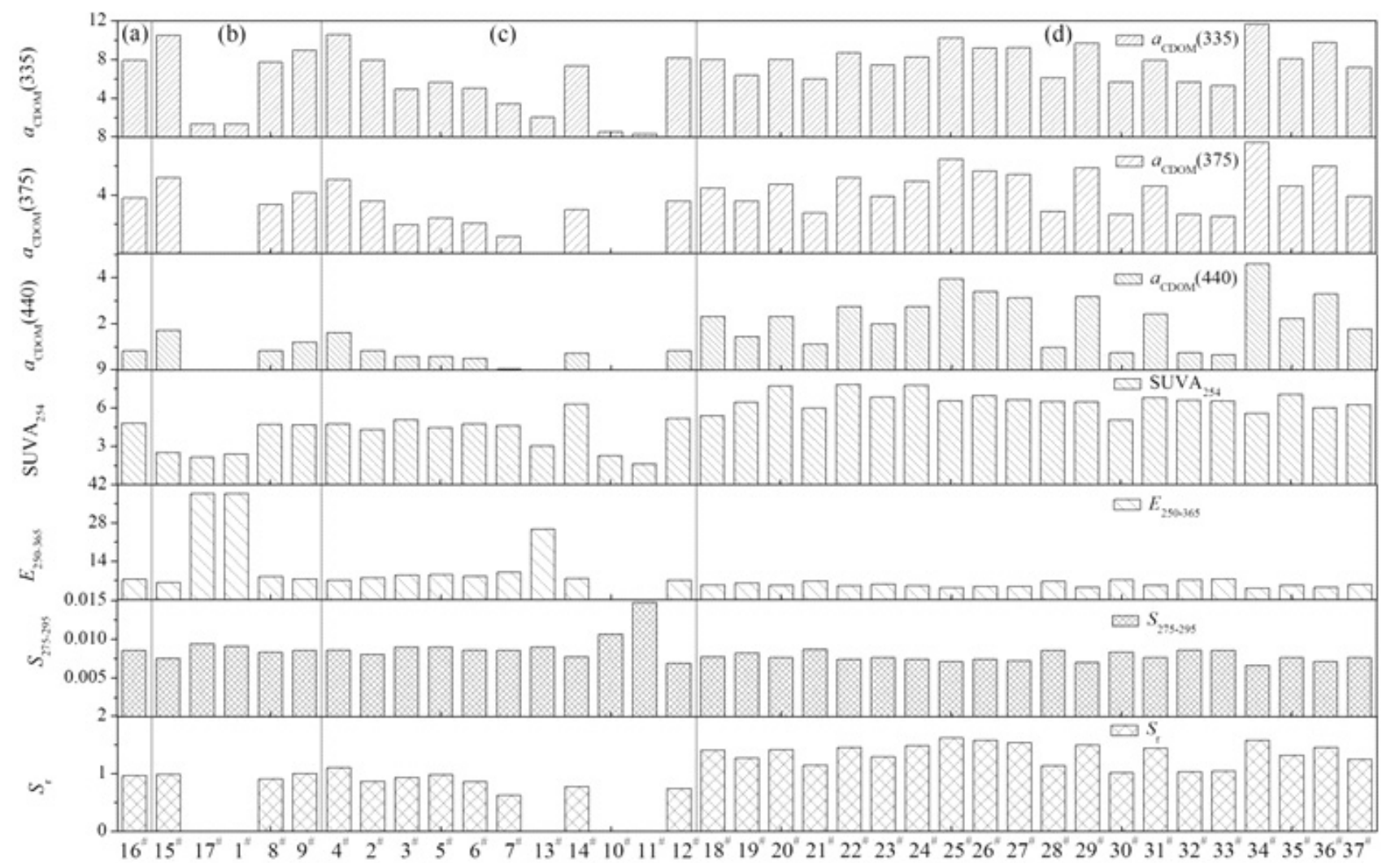

Fig. 5. Histogram of $a_{\mathrm{CDOM}}(335), a_{\mathrm{CDOM}}(375), a_{\mathrm{CDOM}}(440), \mathrm{SUVA}_{254}, E_{250: 365}, S_{275-295}$, and $S_{\mathrm{r}}$ by gray dot line in different samplings: a) the confluence of the Yinma and Yitong Rivers (No. 16), b) Yitong River, c) Yinma River, and d) STKM reservoir. The unit SUVA 254 was $\mathrm{L} \mathrm{mg} \mathrm{C}^{-1} \mathrm{~m}^{-1}$.

transforms to the low molecular weight DOM due to lightdegradation and biodegradation [52-53]. Accounting for the process of mixed diluted and degradated in the terminal waters, the rivers gradually showed the high molecular weight DOM. Brooks et al. (2007) [54] indicated that the process of photochemical degradation can decrease the aromatics of DOM. Terminal waters gradually showed the low molecular weight DOM. However, the watershed collected waters from main tributaries, which drain very different areas with respect to petrology, tectonics, and vegetation. It is expected that nutrients and CDOM components could be quite different from other water masses. A light bleaching process was not an important factor.

These terrigenous inputs resulting in high loads of suspended matter prevented phytoplankton from growing due to light limitation. On the other hand, they also limited microbial activity. A possible explanation for the diverse results may be human disturbance factors, e.g., landscape especially for cropland and the residential land

Table 1. CDOM absorption parameters of water samples collected from the watershed, STKM reservoir, and the Yitong and Yinma rivers.

\begin{tabular}{|c|c|c|c|c|c|c|c|c|}
\hline \multirow{2}{*}{ Parameter } & \multicolumn{2}{|c|}{ Watershed } & \multicolumn{2}{c|}{ Reservoir } & \multicolumn{2}{c|}{ Yitong River } & \multicolumn{2}{c|}{ Yinma River } \\
\cline { 2 - 9 } & Mean & Min-Max & Mean & Min-Max & Mean & Min-Max & Mean & Min-Max \\
\hline$a_{\text {CDOM }}(335)$ & $5.51 \pm 3.47$ & $0.31-10.59$ & $7.93 \pm 1.73$ & $5.32-11.66$ & $5.97 \pm 4.33$ & $1.36-10.49$ & $5.08 \pm 3.30$ & $0.31-10.59$ \\
\hline$a_{\text {CDOM }}(375)$ & $2.31 \pm 1.84$ & $0-5.18$ & $4.52 \pm 1.42$ & $2.53-7.60$ & $2.53 \pm 2.40$ & $0-5.18$ & $2.07 \pm 1.68$ & $0-5.07$ \\
\hline$a_{\text {CDOM }}(440)$ & $0.60 \pm 0.56$ & $0-1.71$ & $2.28 \pm 1.12$ & $0.65-4.6$ & $0.74 \pm 0.75$ & $0-1.71$ & $0.52 \pm 0.50$ & $0-1.61$ \\
\hline$E_{250: 365}$ & $11.66 \pm 11.5$ & $0-38.7$ & $5.50 \pm 1.02$ & $4.09-7.44$ & $19.89 \pm 17.2$ & $6.25-38.7$ & $8.31 \pm 6.69$ & $0-25.68$ \\
\hline SUVA $_{254}$ & $3.97 \pm 1.35$ & $1.61-6.28$ & $6.54 \pm 0.74$ & $5.04-7.83$ & $3.29 \pm 1.29$ & $2.15-4.71$ & $4.21 \pm 1.37$ & $1.61-6.28$ \\
\hline$S_{275-295}$ & 0.0089 & 0.0069 & 0.0077 & 0.0066 & 0.0086 & 0.0075 & 0.0091 & 0.0069 \\
\hline$S_{\mathrm{r}}$ & $0.63 \pm 0.43$ & $0-1.10$ & $1.34 \pm 0.19$ & $1.01-1.61$ & $0.58 \pm 0.53$ & $0-1$ & $0.62 \pm 0.42$ & $0-1.1$ \\
\hline
\end{tabular}

Absorption coefficient units of CDOM are $\mathrm{m}^{-1}$ and the $\mathrm{SUVA}_{254}$ unit is $\mathrm{L} \mathrm{mg} \mathrm{C}^{-1} \mathrm{~m}^{-1}$. 
that the rivers flow through. These processes brought more polycyclic aromatic hydrocarbons, pesticides, and organic pollutants to the waters. Algal-derived DOC had lower color intensity than DOC from the decomposition of woody vegetation (humic-derived DOC), and DOC from human sources (e.g., wastewater effluent) is nearly uncolored [55]. As a matter of fact, Chinese farmers prefer chemical fertilizer to organic fertilizer. Owing to the influence of biological species and thermodynamics in lake ecological systems, it exhibited significant differences between riverine and reservoir waters. Meanwhile, relatively high molecular DOC fractions accumulated in waters due to a period of lake residence as long as decades. Future research may be able to link the integrating effects of anth ropogenic and natural factors.

\section{Relative Contributions of CDOM Absorption}

The relative contributions at $440 \mathrm{~nm}$ are shown in Fig.6, and there was an obvious difference in the relative contributions of CDOM, phytoplankton, and non-algal particles between riverine and reservoir waters. The mean contribution of CDOM to total contributions was $12.5 \%$ $(0 \sim 30 \%)$ in riverine waters and $43.4 \%(16 \sim 63 \%)$ in the reservoir. The relative contribution of non-algal particles and phytoplankton were on mean $78.1 \%(20 \sim 100 \%)$ and $36.4 \%(21 \sim 58 \%)$ in riverine waters, and $9.4 \%(0 \sim 50 \%)$ and $20.1 \%(13 \sim 32 \%)$ in the reservoir.

Non-algal particle absorption played an important role in total non-water light absorption for the riverine waters, and the same as CDOM in the reservoir. The mean relative contribution of CDOM (YT, 14\%; YM, $11.1 \%$ ), non-algal particles (YT, 70\%; YM, 83.8\%) and phytoplankton (YT, 16.1\%; YM, 5\%) in the Yitong and Yinma rivers were consistent with the change of water quality. Non-algal particles in the inland, shallow, or coastal waters often exceeded the phytoplankton $[52,56]$. Especially for the waters with low CDOM concentrations, the non-algae particle proportion has a great influence on relative contribution. The differences in the contributions of phytoplankton and CDOM to total absorption could influence the maximum photosynthetic rate and determine the photochemical mineralization of DOC [19, 44]. Additionally, the high concentration of non-algal particles increases the difficulty of ing the $a_{\mathrm{dg}}(\lambda)$ (the sum absorption coefficient of non-algal particle and CDOM) based on many semi-analytical algorithms, e.g., QAA algorithms [57-59].

\section{Relationship between Water Quality and Light Absorption}

Pearson correlation between the CDOM absorption coefficient $\left[a_{\text {CDOM }}(335), a_{\text {CDOM }}(375), a_{\text {CDOM }}(440)\right]$ and DOC showed that there was a positive correlation between them (Table 2). The correlation coefficients were $0.82^{* *}, 0.84^{* *}$, and $0.90^{* *}$ in the riverine waters, and $0.64^{* *}, 0.62^{* *}$, and $0.60^{* *}$ in the reservoir waters (twotailed, $\mathrm{p}<0.01)$ (Table 2). Meanwhile, there was a good linear relationship between $a_{\mathrm{CDOM}}(440)$ and DOC in the riverine waters in comparison to the reservoir waters (Fig. 7). Previous research confirmed that when CDOM and DOC co-vary, and UCDOM is constant in DOC or a constant ratio of CDOM to DOC exists, there should be a good relationship between CDOM and DOC [60]. CDOM dynamically converts to UCDOM based on the degraded and photochemical processes, resulting in some absorbing
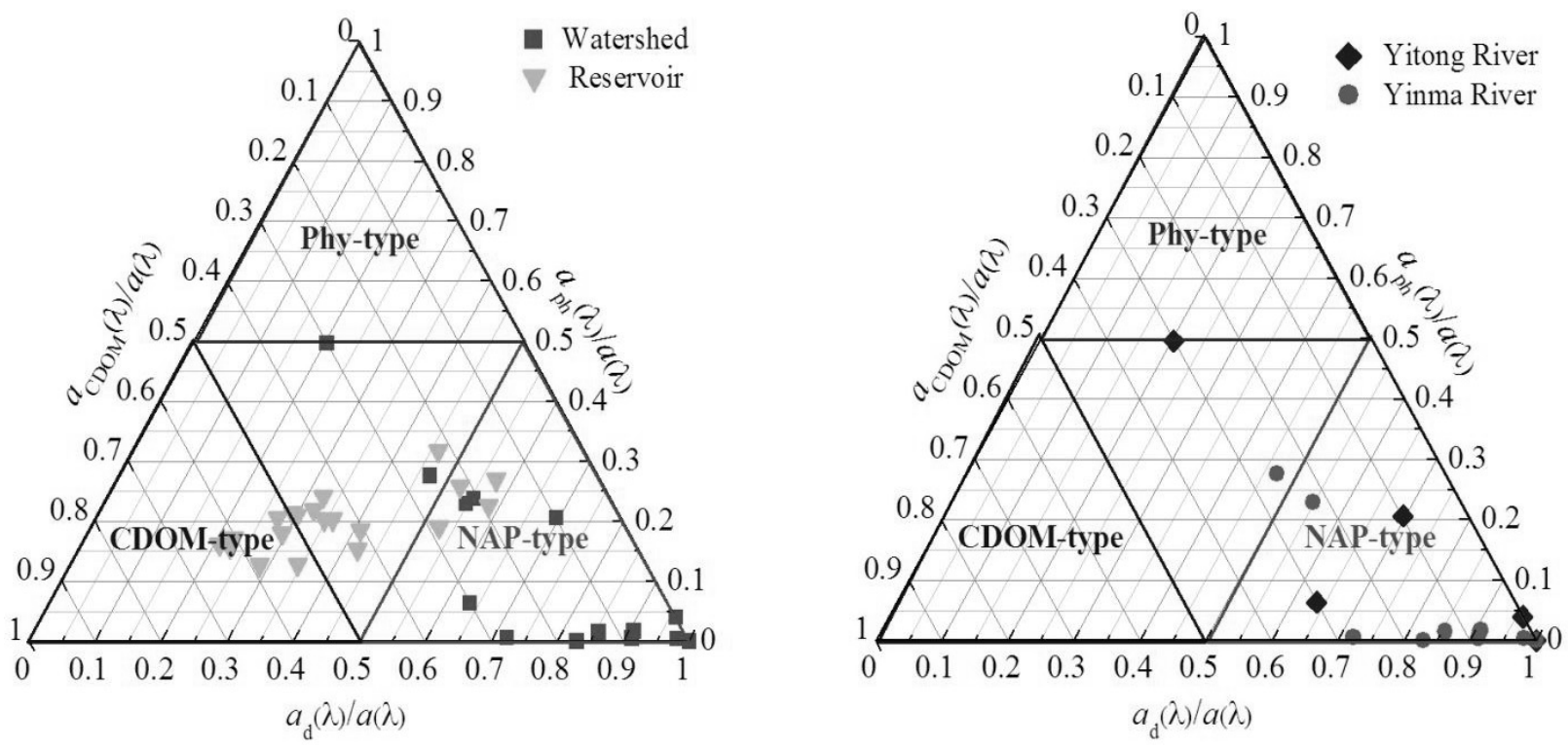

Fig. 6. Relative contributions of CDOM, phytoplankton, and non-algal particles to total non-water light absorption at $440 \mathrm{~nm}$. According to the optical classification of surface waters (Prieur and Sathyendranath, 1981), the relative contribution of collected water samplings could be classified as "CDOM-type", "non-algal particles type (NAP-type)," and "phytoplankton-type (Phy-type)" due to the variation of water quality parameters. 
Table 2. Pearson correlation analysis between water quality and light absorption properties.

\begin{tabular}{|c|c|c|c|c|c|c|}
\hline & \multicolumn{2}{|c|}{ DOC } & \multicolumn{2}{c|}{ TSM } & \multicolumn{2}{c|}{ Chl-a } \\
\cline { 2 - 7 } & Watershed & Reservoir & Watershed & Reservoir & Watershed & Reservoir \\
\hline$a_{\text {CDOM }}(335)$ & $0.82^{\mathrm{b}}$ & $0.64^{\mathrm{b}}$ & -0.47 & -0.05 & $0.51^{\mathrm{a}}$ & $0.50^{\mathrm{a}}$ \\
\hline$a_{\mathrm{CDOM}}(375)$ & $0.84^{\mathrm{b}}$ & $0.62^{\mathrm{b}}$ & $0.51^{\mathrm{b}}$ & -0.09 & $0.54^{\mathrm{a}}$ & $0.50^{\mathrm{a}}$ \\
\hline$a_{\mathrm{CDOM}}(440)$ & $0.90^{\mathrm{b}}$ & $0.60^{\mathrm{b}}$ & -0.46 & -0.11 & $0.61^{\mathrm{a}}$ & $0.49^{\mathrm{a}}$ \\
\hline$E_{250: 365}$ & -0.27 & $-0.50^{\mathrm{b}}$ & $0.95^{\mathrm{b}}$ & 0.07 & -0.22 & -0.44 \\
\hline $\mathrm{SUVA}_{254}$ & 0.7 & $-0.69^{\mathrm{b}}$ & -0.46 & -0.04 & -0.15 & 0.28 \\
\hline$S_{275-295}$ & -0.44 & $-0.57^{\mathrm{b}}$ & 0.04 & 0.07 & -0.23 & $-0.48^{\mathrm{a}}$ \\
\hline$S_{\mathrm{r}}$ & $0.64^{\mathrm{b}}$ & 0.42 & $-0.60^{\mathrm{a}}$ & -0.09 & 0.37 & $0.48^{\mathrm{a}}$ \\
\hline
\end{tabular}

${ }^{\mathrm{a}} \mathrm{p}<0.05 ;{ }^{\mathrm{b}} \mathrm{p}<0.01$

Units of DOC and TSM concentrations are $\mathrm{mg} \mathrm{L}^{-1}$, Chl-a concentration unit is $\mu \mathrm{g} \mathrm{L}^{-1}$, and the $\mathrm{SUVA}_{254}$ unit is $\mathrm{L} \mathrm{mg} \mathrm{C}^{-1} \mathrm{~m}^{-1}$.

molecules, e.g., bacteria taking-up non-absorbing CDOM molecules and to produce absorbing molecules [31, 53, 61]. This indicated that the more active metabolic activity by microorganisms was found in aquatic environments, e.g., reservoir waters.

For the riverine waters it is possible to calculate the flux of DOC base on the positive relationship between the DOC and CDOM. However, this relationship was highly variable for the inland waters in different regions and seasons due to the effects of terrigenous vegetation and non-algal particles, and the ratio was not consistent through the deformation of CDOM and DOC [62].

For the reservoir waters, a close negative correlation between the DOC and CDOM absorption parameters (e.g., SUVA ${ }_{254}, E_{250: 365}$ and $S_{275-290}$ ), and the correlation coefficient were $-0.69^{*},-0.50^{* *}$, and $-0.57^{* *}$, respectively (two-tailed, $\mathrm{p}<0.05$ ) (Table 2). There was no correlation in riverine waters, and similar conclusions from the Liqurian and Mediterranean seas were examined [13,
63]. However, there was no correlation with DOC and $S_{\mathrm{r}}$ in reservoir waters, but the opposite in riverine waters $\left(0.64^{* *}\right.$; two-tailed, $\left.\mathrm{p}<0.01\right)$ (Table 2). Positive correlation existed between DOC and $\mathrm{SUVA}_{254}$, suggesting more colored parts of organic carbon in the humic acid of DOM in reservoir waters. Fichot et al. (2012) [48] found that it is possible to estimate the contribution of vascular plant specie to DOM based on the positive correlation between $S_{275-290}$ and lignin phenols. This has the potential to further explore the relationship between the spectral slope and lignin and derive phenols.

Meanwhile, $a_{\mathrm{CDOM}}(335), a_{\mathrm{CDOM}}(375)$, and $a_{\mathrm{CDOM}}(440)$ showed significantly positive correlation with Chl-a, and the correlation coefficients were above $0.50^{*}$ (two-tailed, $\mathrm{p}<0.05$ ) (Table 2). It was found that negative correlation was examined between Chl-a and $S_{275-295}$ in reservoir waters, and positive correlation with $S_{\mathrm{r}}$ (two-tailed, $\mathrm{p}<0.05$ ) (Table 2), even if the low Chl-a concentration and part of CDOM remain derived from the degradation of phytoplankton.
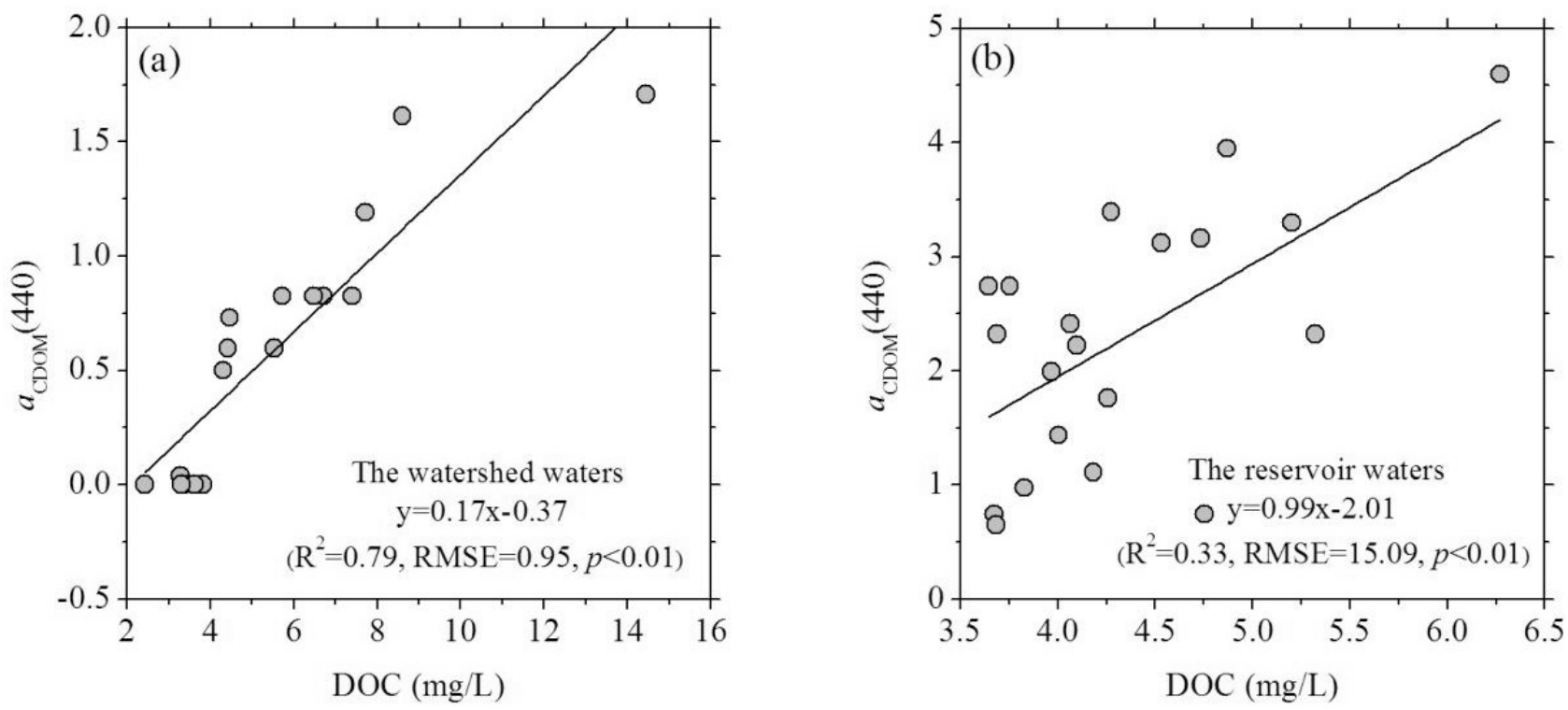

Fig. 7. Correlations between $a_{\mathrm{CDOM}}(355)$ and DOC: a) riverine waters and b) reservoir waters. 
Particularly, the close positive correlations were shown in riverine waters between TSM and $a_{\text {CDOM }}(375)$ and $\mathrm{E}_{250: 365}$, and negative correlation with $S_{\mathrm{r}}$ (two-tailed, $\mathrm{p}<0.05$ ) (Table 2). Some studies confirmed that non-algal particles could affect absorption due to the high concentration of TSM [10]

\section{Conclusion}

Our research shows knowledge of CDOM optical properties and spatial discrepancy based on the relationship between water quality and spectral parameters in the Yinma River watershed with in-situ water data. Diverse results were obtained from spectral parameters, e.g., $a_{\text {CDOM }}(335,375$ and $440 \mathrm{~nm}), \mathrm{SUVA}_{254}, E_{250: 365}, S_{275-290}$, and $S_{\mathrm{r}}$ in the riverine and reservoir waters. The following conclusions were made:

1. A siginificant difference in water quality concentration was observed for riverine and reservoir waters $(p<0.05)$. Terrestrial inputs (especially human effluent organic matter) were the main causes of a wide range of water quality.

2. CDOM in riverine waters had lower aromaticity, molecular weight, and vascular plant contribution than in reservoir waters due to the strong influence of artificial discharge.

Early attempts of CDOM-related remote sensing focused on estimations from open sea environments where CDOM absorption is generally low and spatially honogeneous [10]. Futhermore, attempting this in optically complex waters was explored with remote sensing imagery [10]. These data sets in this research were collected from typical highly turbid inland waters intensely affected by human activities.

Optically active constituents in inland turbid waters are not correlated with each other when they are highly covaried in the oceanic and coastal waters. $a_{\mathrm{g}}(\lambda)$ may not show the completely exponential function, which varied based on the response of water quality concentrations to the environmental and spatial conditions.

Results in this research are more appropriate for the empirical algorithms (e.g., single band model or band ratio model) to retrieve CDOM. Thus the semianalytical algorithms (e.g., QAA-v4/v5) based on radiative transfer equations are sensitive to changes in the specific composition of water constituents, showing more uncertainties in deriving CDOM (DOC). In the future we will focus on verification and optimization of the CDOM algorithm in riverine waters based on satellite remote sensing.

\section{Acknowledgements}

This study was financially supported by the National Major Program of Water Pollution Control and Treatment Technology of China under Grant No. 2014ZX07201011-002.

\section{References}

1. GONNELli M., VESTRI S., SANTINELli C. Chromophoric dissolved organic matter and microbial enzymatic activity. A biophysical approach to understand the marine carbon cycle. Biophysical chemistry. 182, 79, 2013.

2. BATTIN T. J., KAPLAN L.A., FINDLAY S., HOPKINSON C.S., MARTI E., PACKMAN A.I., NWEBOLD J.D., SABATER, F. Biophysical controls on organic carbon fluxes in fluvial networks. Nature Geoscience. 1 (2), 95, 2008.

3. YAN L., JIANG L., TANG Y., YU H., SHENG S.,Yu G. Investigating the Effects of Small Synthetic Organic Matters on Dissolved Organic Matter Adsorption. Water, Air, \& Soil Pollution. 226 (11), 1, 2015.

4. AIKEN G.R., HSU-KIM H., RYAN J.N. Influence of dissolved organic matter on the environmental fate of metals, nanoparticles, and colloids. Environmental science \& technology. 45 (8), 3196, 2011.

5. SPENCER R.G., BUTLER K.D., AIKEN G.R. Dissolved organic carbon and chromophoric dissolved organic matter properties of rivers in the USA. Journal of Geophysical Research: Biogeosciences (2005-2012). 117(G3), 2012.

6. COBLE P.G. Marine optical biogeochemistry: the chemistry of ocean color. Chemical reviews. 107 (2), 402, 2007.

7. CHEN Z., LI Y., PAN J. Distributions of colored dissolved organic matter and dissolved organic carbon in the Pearl River Estuary, China. Continental Shelf Research. 24 (16), 1845,2004

8. COLE J.J., PRAIRIE Y.T., CARACO N.F., MCDOWELL W.H., TRANVIK L.J., STRIEGL R.G., DUARTE C.M., KORTELAINEN P., DOWNING J.A., MIDDELBURG J.J., MELACK, J. Plumbing the global carbon cycle: integrating inland waters into the terrestrial carbon budget. Ecosystems. 10 (1), 172, 2007.

9. SPENCER R.G., STUBBINS A., HERNES P.J., BAKER A., MOPPER K., AUFDENKAMPE A.K., RACHAEL Y.D., VINCENTLM., MANGANGUA.M., WABAKANGHANZI J.N., SIX J. Photochemical degradation of dissolved organic matter and dissolved lignin phenols from the Congo River. Journal of Geophysical Research: Biogeosciences (20052012). 114(G3), 2009.

10. ZHU W., YU Q., TIAN Y.Q., BECKER B.L., ZHENG T., CARRICK H.J. An assessment of remote sensing algorithms for colored dissolved organic matter in complex freshwater environments. Remote Sensing of Environment. 140, 766, 2014.

11. SONG K., LI L., TEDESCO L.P., LI S., HALL B.E., DU J. Remote quantification of phycocyanin in potable water sources through an adaptive model. ISPRS Journal of Photogrammetry and Remote Sensing. 95, 68, 2014.

12. WEN Z.D., SONG K.S., ZHAO Y., DU J., MA J.H. Influence of environmental factors on spectral characteristic of chromophoric dissolved organic matter (CDOM) in Inner Mongolia Plateau, China. Hydrology \& Earth System Sciences Discussions. 12 (6), 5895, 2015.

13. ORGANELLI E., BRICAUD A., ANTOINE D., MATSUOKA A. Seasonal dynamics of light absorption by chromophoric dissolved organic matter (CDOM) in the NW Mediterranean Sea (BOUSSOLE site). Deep Sea Research Part I: Oceanographic Research Papers. 91, 72, 2014.

14. MATSUOKA A., HOOKER S.B., BRICAUD A., GENTILI B., BABIN M. Estimating absorption coefficients of colored dissolved organic matter (CDOM) using a semi-analytical algorithm for southern Beaufort Sea waters: application to 
deriving concentrations of dissolved organic carbon from space. Biogeosciences. 10 (2), 917, 2013.

15. WILLIAMSON C.E., ROSE K.C. When UV meets fresh water. Science (Washington). 329 (5992), 637, 2010.

16. STEDMON C.A., THOMAS D.N., PAPADIMITRIOU S., GRANSKOG M.A., DIECKMANN G.S. Using fluorescence to characterize dissolved organic matter in Antarctic sea ice brines. Journal of Geophysical Research: Biogeosciences (2005-2012), 116(G3), 2011.

17. CORY R.M., MCKNIGHT D.M., CHIN Y.P., MILLER P., JAROS C.L. Chemical characteristics of fulvic acids from Arctic surface waters: Microbial contributions and photochemical transformations. Journal of Geophysical Research: Biogeosciences (2005-2012). 112, 2007.

18. LEDESMA J.L., KöHLER S.J., FUTTER M.N. Long-term dynamics of dissolved organic carbon: Implications for drinking water supply. Science of the total Environment. 432, 1, 2012.

19. ZHANG Y., QIN B., ZHU G., ZHANG L., YANG L. Chromophoric dissolved organic matter (CDOM) absorption characteristics in relation to fluorescence in Lake Taihu, China, a large shallow subtropical lake. Hydrobiologia. $\mathbf{5 8 1}$ (1), 43, 2007.

20. JAFFÉ R., MCKNIGHT D., MAIE N., CORY R., MCDOWELL W.H., CAMPBELL J.L. Spatial and temporal variations in DOM composition in ecosystems: The importance of long-term monitoring of optical properties. Journal of Geophysical Research: Biogeosciences (20052012). 113(G4), 2008

21. SIEGEL D.A., MARITORENA S., NELSON N.B., BEHRENFELD M.J. Independence and interdependencies among global ocean color properties: Reassessing the bioptical assumption. Journal of Geophysical Research: Oceans (1978-2012). 110(C7), 2005.

22. MANN P.J., DAVYDOVA A., ZIMOV N., SPENCER R.G.M., DAVYDOV S., BULYGINA, E., ZIMOV, S., HOLMES, R. M. Controls on the composition and lability of dissolved organic matter in Siberiass Kolyma River basin. Journal of Geophysical Research: Biogeosciences (2005-2012). 117(G1), 2012.

23. HEDGES J.I., KEIL R.G., BENNER R. What happens to terrestrial organic matter in the ocean?.Organic geochemistry. 27 (5), 195, 1997.

24. PHONG D.D., LEE Y., SHIN K.H., HUR J. Spatial variability in chromophoric dissolved organic matter for an artificial coastal lake (Shiwha) and the upstream catchments at two different seasons. Environmental Science and Pollution Research. 21 (12), 7678, 2014.

25. JIANG R., HATANO R., ZHAO Y., KURAMOCHI K., HAYAKAWA A., WOLI K.P., SHIMIZU M. Factors controlling nitrogen and dissolved organic carbon exports across timescales in two watersheds with different land uses. Hydrological processes. 28 (19), 5105, 2014.

26. STEDMON C.A., MARKAGER S., KAAS H. Optical properties and signatures of chromophoric dissolved organic matter (CDOM) in Danish coastal waters. Estuarine, Coastal and Shelf Science. 51 (2), 267, 2000.

27. XIE H., AUBRY C., ZHANG Y., SONG G. Chromophoric dissolved organic matter (CDOM) in first-year sea ice in the western Canadian Arctic. Marine Chemistry. 165, 25, 2014.

28. WEISHAAR J.L., AIKEN G.R., BERGAMASCHI B.A., FRAM M.S., FUJII R., MOPPER K. Evaluation of specific ultraviolet absorbance as an indicator of the chemical composition and reactivity of dissolved organic carbon. Environmental Science \& Technology. 37 (20), 4702, 2003
29. SHAO T., SONG K., DU J., ZHAO Y., DING Z., GUAN Y., LIU L., ZHANG B. Seasonal Variations of CDOM Optical Properties in Rivers Across the Liaohe Delta. Wetlands. 1, 2015.

30. HELMS J.R., STUBBINS A., RITCHIE J.D., MINOR E.C., KIEBER D.J., MOPPER K. Absorption spectral slopes and slope ratios as indicators of molecular weight, source, and photobleaching of chromophoric dissolved organic matter. Limnology and Oceanography. 53 (3), 955, 2008.

31. NELSON N.B., SIEGEL D.A., CARLSON C.A., SWAN C.M. Tracing global biogeochemical cycles and meridional overturning circulation using chromophoric dissolved organic matter. Geophysical Research Letters. 37 (3), 2010.

32. COBLE P.G. Characterization of marine and terrestrial DOM in seawater using excitation-emission matrix spectroscopy. Marine chemistry. 51 (4), 325, 1996.

33. STEDMON C.A., MARKAGER S. Resolving the variability in dissolved organic matter fluorescence in a temperate estuary and its catchment using PARAFAC analysis. Limnology and Oceanography. 50 (2), 686, 2005.

34. LIU H., QI W.B., YU D.W., XIE X.M. Study on Ecological Operation in Yinmahe River Basin. Journal of China hydrology. 33, 35, 2013.

35. ZHOU J., GAO F., ZHANG B., BIAO M. Assessment on the potential biological toxicity risk of toxic heavy metals in the surficial sediments of Songhua River. Acta Scientiae Circumstantiae. 34, 2701, 2014,

36. INAMDAR S.P., O'LEARY N., MITCHELL M.J., RILEY J.T. The impact of storm events on solute exports from a glaciated forested watershed in western New York, USA. Hydrological Processes. 20, 3423, 2006.

37. PELLERIN B.A., SARACENO J.F., SHANLEY J.B., SEBESTYEN S.D., AIKEN G.R., WOLLHEIM W.M., BERGAMASCHI, B. A. Taking the pulse of snowmelt: in situ sensors reveal seasonal, event and diurnal patterns of nitrate and dissolved organic matter variability in an upland forest stream. Biogeochemistry. 108, 183, 2012.

38. SONG K., LI L., WANG Z., LIU D., ZHANG B., XU J., DU J., LI L., LI S., WANG Y. Retrieval of total suspended matter (TSM) and chlorophyll-a (Chl-a) concentration from remotesensing data for drinking water resources. Environmental monitoring and assessment. 184, 1449, 2012.

39. BRICAUD A., MOREL A., PRIEUR L. Absorption by dissolved organic matter of the sea (yellow substance) in the UV and visible domains. Limnology and Oceanography. 26, 43, 1981.

40. POPE R. M., FRY E. S. Absorption spectrum (380-700 nm) of pure water. II. Integrating cavity measurements. Applied Optics. 36 (33), 8710, 1997.

41. MILLER W.L. Effects of UV radiation on aquatic humus: Photochemical principles and experimental considerations// Aquatic Humic Substances. Springer Berlin Heidelberg. $125,1998$.

42. DE HAAN H., DE BOER T. Applicability of light absorbance and fluorescence as measures of concentration and molecular size of dissolved organic carbon in humic Lake Tjeukemeer. Water Research. 21 (6), 731, 1987.

43. PEURAVUORI J., PIHLAJA K. Molecular size distribution and spectroscopic properties of aquatic humic substances. Analytica Chimica Acta. 337, 133, 1997.

44. ZHANG Y., ZHANG E., YIN Y., VAN DIJK M.A., FENG L., SHI Z., LIU M., QINA B. Characteristics and sources of chromophoric dissolved organic matter in lakes of the Yungui Plateau, China, differing in trophic state and altitude. Limnology and Oceanography. 55, 2645, 2010.

45. SONG K.S., ZANG S.Y., ZHAO Y., LI L., DU J., 
ZHANG N.N., WANG X.D., SHAO T.T., GUAN Y., LIU L. Spatiotemporal characterization of dissolved carbon for inland waters in semi-humid/semi-arid region, China. Hydrology and Earth System Sciences. 17, 4269, 2013.

46. BAKER A., BOLTON L., NEWSON M., SPENCER R.G. Spectrophotometric properties of surface water dissolved organic matter in an afforested upland peat catchment. Hydrological Processes. 22, 2325, 2008.

47. ASMAILA E., AUTIO R., KAARTOKALLIO H., PITKÄNEN L., STEDMON C., THOMAS D.N. Bioavailability of riverine dissolved organic matter in three Baltic Sea estuaries and the effect of catchment land use. Biogeosciences. 10, 6969, 2013.

48. FICHOT C.G., BENNER R. The spectral slope coefficient of chromophoric dissolved organic matter $\left(\mathrm{S}_{275-295}\right)$ as a tracer of terrigenous dissolved organic carbon in river-influenced ocean margins. Limnology and Oceanography. 57, 1453, 2012.

49. MANNINO A., RUSS M.E., HOOKER S.B. Algorithm development and validation for satellite-derived distributions of DOC and CDOM in the US Middle Atlantic Bight. Journal of Geophysical Research: Oceans (1978-2012). 113 (C7), 2008.

50. STEDMON C.A., BRO R. Characterizing dissolved organic matter fluorescence with parallel factor analysis: a tutorial. Limnology and Oceanography: Methods. 6, 572, 2008.

51. CARDER K.L., STEWARD R.G., HARVEY G.R., ORTNER P.B. Marine humic and fulvic acids: Their effects on remote sensing of ocean chlorophyll. Limnology and oceanography. 34, 68, 1989.

52. CARDER K.L., HAWES S.K., BAKER K.A., SMITH R., STEWARD R.G., MITCHELL B.G. Reflectance model for quantifying chlorophyll a in the presence oi productivity degradation products. Journal of Geophysical Research. 96, 20599, 1991.

53. VODACEK A., BLOUGH N.V., DEGRANDPRE M.D., NELSON R.K. Seasonal variation of CDOM and DOC in the Middle Atlantic Bight: Terrestrial inputs and photooxidation. Limnology and Oceanography. 42, 674, 1997.

54. BROOKS P.D., LEMON M.M. Spatial variability in dissolved organic matter and inorganic nitrogen concentrations in a semiarid stream, San Pedro River, Arizona. Journal of
Geophysical Research: Biogeosciences (2005-2012). 112, 2007.

55. BREZONIK P.L., OLMANSON L.G., FINLAY J.C., BAUER M.E. Factors affecting the measurement of CDOM by remote sensing of optically complex inland waters. Remote Sensing of Environment. 157, 199, 2015.

56. FRENETTE J.J., ARTS M.T., MORIN J. Spectral gradients of downwelling light in a fluvial lake (Lake Saint-Pierre, StLawrence River). Aquatic Ecology. 37, 77, 2003.

57. LEE Z.P., CARDER K.L., ARNONE R.A. Deriving inherent optical properties from water color: a multiband quasianalytical algorithm for optically deep waters. Applied optics. 41, 5755, 2002.

58. LEE Z., LUBAC B., WERDELL J., ARNONE R. An update of the quasi-analytical algorithm (QAA v5). International Ocean Color Group Software Report. 2009.

59. ZHENG G.M., STRAMSKI D., REYNOLDS R.A. Evaluation of the quasi-analytical algorithm for estimating the inherent optical properties of seawater from ocean color: comparison of Arctic and lower-latitude waters. Remote Sensing of Environmrnt. 155, 194, 2014.

60. HOGE F.E., VODACEK A., SWIFT R.N., YUNGEL J.K., BLOUGH N.V. Inherent optical properties of the ocean: retrieval of the absorption coefficient of chromophoric dissolved organic matter from airborne laser spectral fluorescence measurements. Applied optics. 34, 7032, 1995.

61. ROCHELLE-NEWALL E.J. Dynamics of chromophoric dissolved organic matter and dissolved organic carbon in experimental mesocosms. International Journal of Remote Sensing. 20, 627, 1999.

62. YU Q., TIAN Y.Q., CHEN R.F., LIU A., GARDNER G.B., ZHU W. Functional linear analysis of in situ hyperspectral data for assessing CDOM in rivers. Photogrammetric Engineering \& Remote Sensing. 76, 1147, 2010.

63. BRACCHINI L., DATTILO A.M., HULL V., LOISELLE S., NANNICINI L., PICCHI M.P., RICCI M., SANTINELLI C., SERITTI A., TOGNAZZI A., ROSSI, C. Spatial and seasonal changes in optical properties of autochthonous and allochthonous chromophoric dissolved organic matter in a stratified mountain lake. Photochemical \& Photobiological Sciences. 9, 304, 2010. 